Publiceringen af de 12 tegninger af Profeten Muhammed i den danske avis Jyllands-Posten medførte hvad der i Danmark blev betegnet som den største udenrigspolitiske krise i nyere tid. Dansk erhvervsliv var hårdt ramt af den omfattende boykot, men er nu atter ved at finde tilbage til niveauet fra før boykotten.

\title{
Dansk erhvervsliv i Mellemøsten
}

Lone Beukel (f. 1974) er cand. negot. og amanuensis ved Center for Mellemøststudier, Syddansk Universitet, Odense. 
TEKST: Lone Beukel

DANSK EKSPORT ER traditionelt karakteriseret ved, at man i høj grad eksporterer til nærområderne, dvs. til de øvrige Eu-lande. Således foregår to tredjedele af den danske eksport til netop disse lande. Siden murens fald har der været øget fokus på de nye markeder de tidligere østbloklande udgør; markederne anses for attraktive pga. deres store befolkninger og stigende økonomiske formåen.

Sideløbende med denne udvikling har den danske eksport til Mellemøsten siden midten af I980'erne været jævnt stigende, og er næsten fordoblet siden starten af I990'erne. I 200I anslog chefkonsulent i Dansk Industri Christian Wittenkamp, at 500 af Danmarks dengang 5900 virksomheder var involveret $i$ handel med Mellemøsten. I 2005 udgjorde den danske eksport til Mellemøsten et samlet beløb på
I2.5 mia. danske kroner, svarende til 2,5 procent af den samlede danske eksport.

Det er således en mindre, men ikke ubetydelig del af dansk eksport, der finder vej til Mellemøsten. Tallene dækker imidlertid over store forskelle indenfor de enkelte varegrupper, ligesom der landene imellem er betydelige forskelle i den værdi af varer, der eksporteres for. (Se Figur I.)

\section{Store markeder}

Saudi Arabien, Tyrkiet, Iran, De Forenede Arabiske Emirater og Israel udgør de største aftagere af danske eksportvarer i den mellemøstlige region målt på den samlede værdi af eksporten. Således aftager landene til sammen mere end 66 procent af den samlede danske eksport til regionen.

Tyrkiet og Saudi Arabien er de absolut største aftagere af danske produkter i regionen. Dansk eksport til Saudi Arabien udgjorde i 2005 et beløb af 2,23 mia. kr., hvoraf halvdelen af eksporten udgøres af fødevarer, herunder mejeriprodukter. Netop fødevareområdet er et af de områder, hvor det saudiske marked forventes at stige og således udgør et potentielt vækstområde, ikke mindst for de virksomheder, der allerede er etableret på markedet og hvis varer de saudiske forbrugere er bekendte med.

Hvad angår Tyrkiet består langt størstedelen af dansk eksport af maskiner, kraftmaskiner og specialmaskiner til industrien samt medicinske og farmaceutiske produkter.

At Iran er blandt de største aftagere af danske varer i Mellemøsten er et forholdsvist nyt fænomen. Siden 2003 er eksporten til Iran fordoblet, og alene i de første 9 måneder af 2005 steg eksporten med 23 procent. Det er især forskellige 


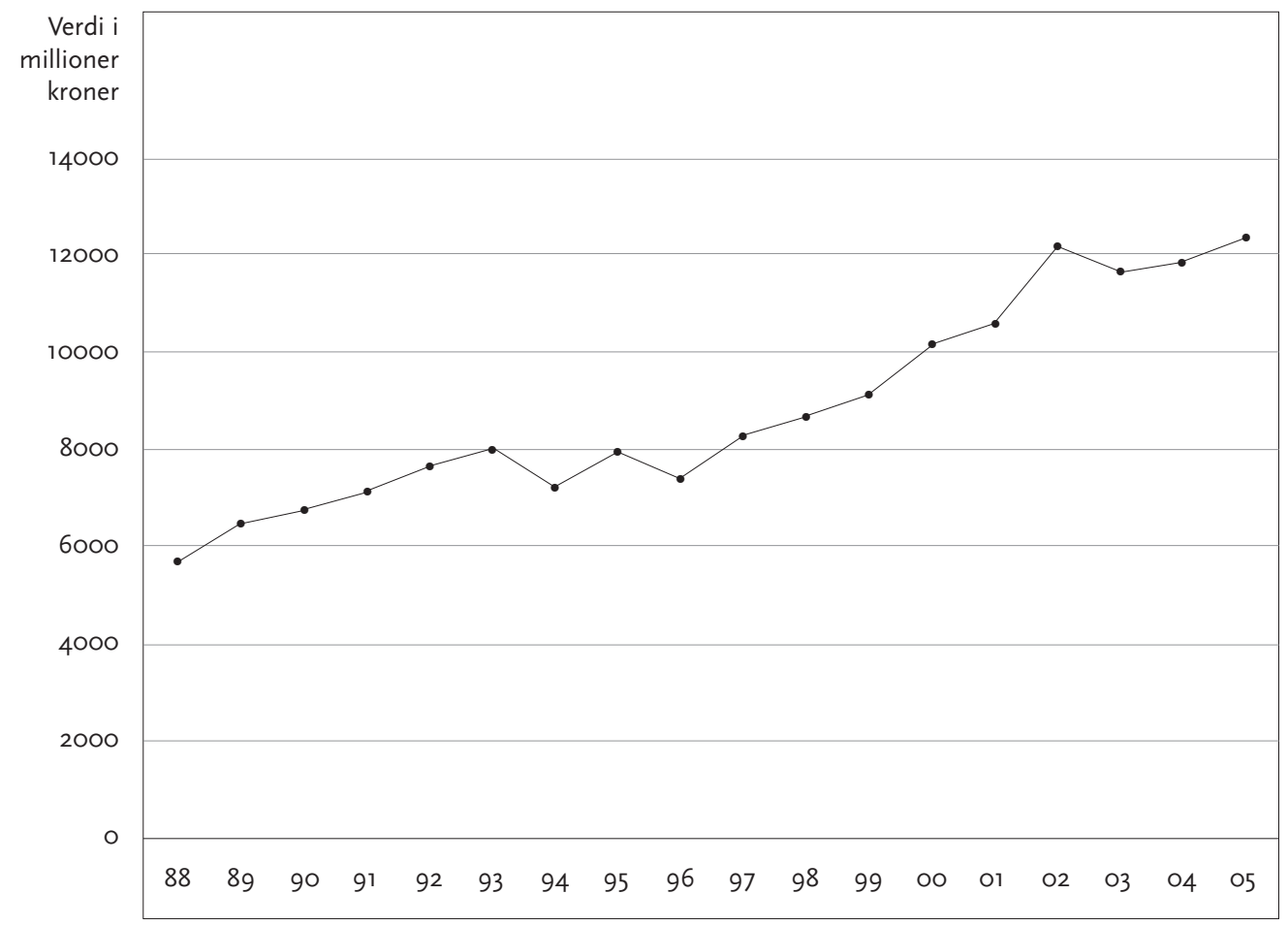

Figur I: Dansk eksport til Mellemøsten I988-2005

maskiner til industrien samt medicinske og farmaceutiske produkter, at Danmark eksporterer til Iran.

De Forenede Arabiske Emirater importerer primært mejeriprodukter, kødvarer og andre næringsmidler fra danske virksomheder. UAE importerede i 2005 danske varer for en samlet værdi af I,457 mia. kr., hvilket er bemærkelsesværdigt, når man ser på det forholdsvis beskedne befolkningstal i landet. Således importerer UAE danske varer for et beløb svarende til $502 \mathrm{kr}$. pr. indbygger, hvilket er det højeste i regionen, mens det tilsvarende tal for Tyrkiet og Saudi Arabien er henholdsvis 33 og 94 kr. pr. indbygger - jf Tabel I.

Medicin er ligeledes en eksportvare, der udgør en stadig stigende del af dansk eksport til Mellemøsten. Sundhedssektoren anses for værende en potentiel vækst sektor, hvor danske og andre skandinaviske firmaer generelt har gode muligheder for at øge omsætningen. Det gælder såvel medicinske og farmaceutiske produkter, som udstyr, møbler mm. til klinikker og institutioner inden for sundhedssektoren. Eksportrådet, der er nedsat af det danske udenrigsministerium med det formål at løse opgaver for private virksomheder inden for eksport, internationalisering og investeringsfremme, fremhæver via sin hjemmeside og øvrige materiale netop De Forenede Arabiske Emirater som et oplagt segment til afsætning af medicinske og farmaceutiske produkter, know-how og udstyr til sundhedssektoren. Eksporten af danske medicinalvarer til De Forenede Arabiske Emirater er de seneste Io år steget med I 65 procent samtidig med, at den samlede danske eksport til landet er mere end for- 


\begin{tabular}{|c|c|c|c|c|}
\hline Land & $\begin{array}{l}\text { Eksport i } 1995 \\
\text { (mio. kr.) }\end{array}$ & $\begin{array}{l}\text { Eksport i } 2000 \\
\text { (mio. kr.) }\end{array}$ & $\begin{array}{l}\text { Eksport i } 2005 \\
\text { (mio. kr.) }\end{array}$ & $\begin{array}{l}\text { Eksport per ind- } \\
\text { bygger i } 2005(\mathrm{kr})^{4}\end{array}$ \\
\hline Algeriet & 102,2 & 178 & 350,8 & 11,21 \\
\hline Bahrain & 117,6 & 129,2 & 123,3 & 176,14 \\
\hline UAE & 776,3 & 1117,5 & 1457,4 & 502,55 \\
\hline Egypten & 911,3 & 1320 & 712,2 & 10,1 \\
\hline Irak & 8 & 163,6 & 226,5 & 9,17 \\
\hline Iran & 492,4 & 460,2 & 1264,5 & 18,57 \\
\hline Israel & 904,5 & 1219,3 & 1185,4 & 188,16 \\
\hline Jordan & 152,3 & 273,3 & 235,5 & 44,43 \\
\hline Kuwait & 307 & 391,6 & 526,9 & 219,54 \\
\hline Libanon & 334 & 352,3 & 325,5 & 90,42 \\
\hline Libyen & 141,2 & 109,8 & 225,2 & 41,7 \\
\hline Marokko & 187,3 & 252,7 & 199,5 & 6,63 \\
\hline Oman & 159,2 & 189,6 & 244,4 & 87,29 \\
\hline
\end{tabular}

Tabel I: Dansk eksport til Mellemøsten fordelt på land i årene I995, 2000 og 2005 samt eksport pr. indbygger i 2005.

doblet. Handikapsektoren, eksempelvis samt fødevarer, herunder særligt kørestole, slisker et cetera, betegnes af mejeriprodukter.

Eksportrådet som en ny sektor, idet man nu - i modsætning til tidligere, hvor handikapområdet var stærkt tabubelagt - begynder at anerkende behovet for genoptræning og udstyr. Der er således grund til på sigt at forvente yderligere vækst til såvel De Forenede Arabiske Emirater som andre golflande med lignende strukturer og behov.

Samlet set er det karakteristisk for de største aftagerlande af danske eksportvarer i Mellemøsten, at de produkter der primært afsættes er maskiner o.lign. til industrien, medicinalvarer og farmaceutiske varer

\section{Mellemstore markeder}

II lande udgør hvad man kan betegne som mellemstore markeder for den danske eksport til regionen: Algeriet, Egypten, Irak, Jordan, Kuwait, Libanon, Libyen, Oman, Qatar, Syrien og Yemen importerer alle for årlige beløb på over 200 mio. kr.

Egypten adskiller sig hvad angår dansk eksport til landet fra de øvrige lande i gruppen af mellemstore markeder. Danmark eksporterede i 2005 for et beløb af 7I2 mio. kr. til landet, og Egypten er dermed en af de største aftagere i gruppen af mellemstore 


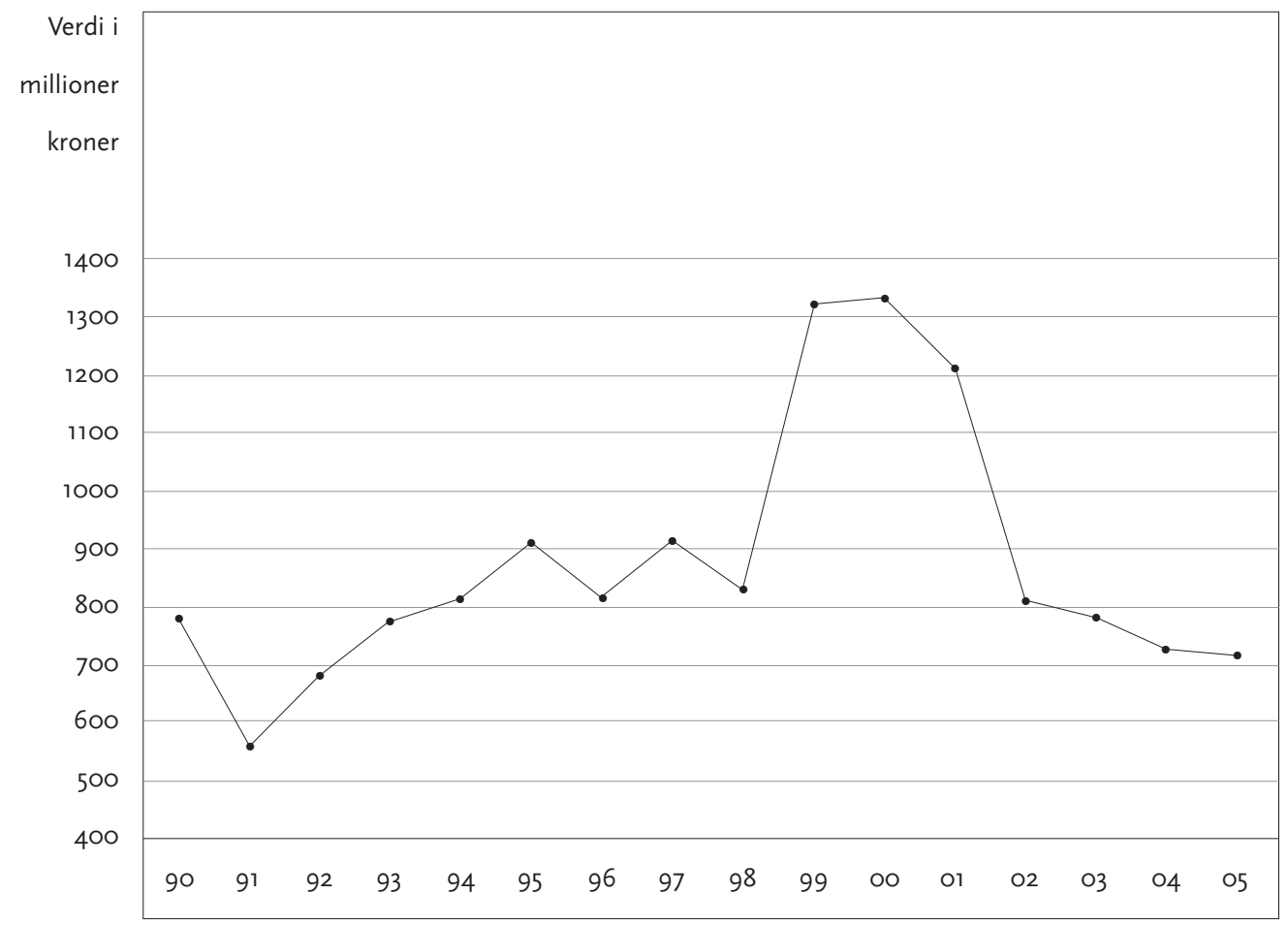

Figur I: Dansk eksport til Egypten I990-2005

markeder. Imidlertid er der siden 2000 , hvor eksporten var på I,32 mia. kr., sket et markant fald i værdien af dansk eksport til Egypten, illustreret på Figur 2.

Faldet i eksporten til Egypten er særligt markant inden for varegrupperne maskiner og specialmaskiner og tekniske og videnskabelige instrumenter, herunder vindmøller, hvor eksporten er mere end halveret siden år 2000. Ligeledes er værdien af eksporten af medicinske og farmaceutiske produkter til Egypten faldet med en tredjedel, og udgjorde i 2005 et samlet beløb af I3I mio. kr. i sammenligning med I96,5 mio. kr. i år 2000. I samme periode er eksporten af mejerivarer steget fra 69 mio. kr. i 2000 til ıı6,8 mio. kr. i år 2005, men samlet set er der sket et ganske markant fald i eksporten til landet. Faldet i den danske eksport tilskrives, ifølge det danske udenrigsministerium, den generelle krise i den egyptiske økonomi. Det egyptiske pund er faldet og dermed købekraften, hvilket har en negativ effekt på værdien af de varer, der eksporteres til landet. Uanset nedgangen må det egyptiske marked med sine mere end 70 mio. indbyggere karakteriseres som et interessant marked i dansk eksport-sammenhæng og der er tegn på, at omlægninger i den egyptiske økonomi vil medføre en tiltrængt vækst. Hvad angår medicinske og farmaceutiske produkter er der dog for Danmark og andre eksporterende lande den omstændighed, at konkurrencen fra kopiprodukter er ganske omfattende og at det er den egyptiske regering, der af sociale hensyn fastsætter prisen på medicinalvarer.

I gruppen af mellemstore markeder udgør golflandene Kuwait og Qatar ganske 
interessante markeder, idet de trods deres i sammenligning med andre lande i regionen, forholdsvis beskedne indbyggertal $\mathrm{i}$ 2005 importerede for henholdsvis 526,9 mio. kr. og 249,I mio. kr. og har udvist en konstant stigende efterspørgsel efter udenlandske, herunder danske, varer. Set i sammenligning med de øvrige lande i regionen er Qatar det land, til hvem Danmark eksporterer for næstmest målt på værdien pr. indbygger, nemlig $4 \mathrm{I} 5 \mathrm{kr}$. per indbygger (jf. Tabel I).

Ligesom det var karakteristisk for landene i gruppen af store markeder udgør mejeriprodukter samt maskiner og medicinske og farmaceutiske produkter de største varegrupper, danske virksomheder afsætter til Kuwait og Qatar, om end afsætningen af danske mejeriprodukter til Qatar har været nogenlunde stabil de seneste fem år. For Qatars vedkommende er det iøjnefaldende, at eksporten af danske møbler er steget betragteligt de seneste fem år; fra 2,5 mio. kr. i år 2000 til I7 mio. kr. i år 2005. Eksporten af møbler til Qatar udgør således beskedne 6 procent af Danmarks eksport til landet, men er ikke desto mindre en varegruppe, der har udvist en ganske høj vækst. Også i de øvrige golflande er møbelmarkedet voksende; købekraften er relativ høj, og i eksempelvis Emiraterne, hvor der investeres kraftigt i byggeri af hoteller og kontorbygninger, er der stor efterspørgsel på importerede møbler indenfor alle priskategorier om end konkurrencen må betegnes som relativ hård.

\section{Små markeder}

Målt på den samlede værdi af eksporten, må landene Bahrain, Marokko, Sudan, Tunesien og Vestbredden/Gaza betegnes som små markeder, idet afsætningen af danske eksportvarer i 2005 udgjorde beløb på under 200 mio. kr.

Det relativt købestærke Bahrain adskiller sig dog fra gruppen af disse små markeder, når man ser på værdien af dansk eksport pr. indbygger, som for Bahrains vedkommende i 2005 var $176 \mathrm{kr}$./indbygger.

\section{Risici}

Som ovenstående viser, er og bør Mellemøsten være en region af interesse for danske og skandinaviske virksomheder inden for en lang række sektorer. Ikke overraskende har regionens mange konflikter en negativ indflydelse på den interesse virksomhederne måtte have. Regionen forbindes med politisk ustabilitet, ugennemskuelig lovgivning og risikofyldte investeringer. Eksemplet Iran viser, at der er mange penge at tjene, men at landets politiske situation samtidig er så konfliktfyldt, at der kan være en ikke ubetydelig risiko ved, i hvert fald i perioder, at gøre forretning i landet. Flere mellemøstlige lande har desuden udmærket sig ved at kræve, at udenlandske virksomheder anvender en lokal agent/sponsor til at distribuere et givet produkt, hvilket vanskeliggør gennemsigtigheden i markedet.

Dertil kommer, at Mellemøsten for skandinaviske og europæiske virksomheders vedkommende ofte opfattes som tidskrævende forstået på den måde, at etablering af kontakt, indledende møder mm. ofte foregår over en forholdsvis lang periode, før den egentlige aftale falder på plads. Sagt med andre ord, er "doing business in the Middle East" en langtidsinvestering, hvor lovgivningsmæssige og kulturelle forskelle har stor indflydelse.

EU har i de forløbne år indgået en række associeringsaftaler med bl.a. Egypten, 
Algeriet Marokko og Tunesien. Aftalerne har til hensigt at forbedre Eus relationer til landene i Middelhavsområdet, og betyder bl.a., at told på varer fra Europa gradvist vil blive afviklet, og at eksisterende procedurer forenkles og standardiseres.

For at fremme interessen for at øge den danske eksport til Mellemøsten har forskellige danske brancheorganisationer flere gange arrangeret eksportfremstød i regionen med tilskud fra Danmarks Eksportråd, der er nedsat af udenrigsministeriet. Hen-

\section{Mellemøsten bør vore en region af interesse for skandinaviske virksomheder inden for en lang roekke sektorer.}

sigten med eksportfremstødene er at give virksomhederne større viden om markedsmuligheder og forretningsvilkår, og samtidig at give danske virksomheder kontakter til forretnings- og samarbejdspartnere på et givent marked. Et eksempel på dette er Landbrugsrådets fødevarefremstød, der skal finde sted i Saudi Arabien, Kuwait og De Forenede Arabiske Emirater i perioden 30. oktober til Io. november i år. Målgruppen på de arabiske markeder er indkøbere og beslutningstagere i supermarkedskæder og fødevaredistributionsselskaber, som på denne måde præsenteres for en lang række danske virksomheder og deres produkter. Samtidig introduceres de medvirkende danske virksomheder direkte for potentielt interessante aftagere og distributører, og kan i nogen grad drage fordel af de erfaringer andre virksomheder har gjort på markederne, hvorved usikkerheds- faktoren mindskes. En begivenhed, der har bekræftet opfattelsen af det mellemøstlige marked som lunefuldt og ustabilt, er den såkaldte "Muhammed-sag", der har haft uanede effekter på dansk eksport.

\section{Muhammed-krise og boykot}

Da den danske avis Jyllands-Posten 30. september 2005 bragte I2 satire-tegninger af Profeten Muhammed var det starten på den i nyere tid største krise for såvel dansk udenrigspolitik som dansk eksport. Efter næsten halvanden måneds debat, statsministerens afvisning af et møde med en række ambassadører fra muslimske lande, sagsanlæg fra II dansk-muslimske organisationer mod Jyllands-Posten for blasfemi og racediskrimination og lejlighedsvise demonstrationer i Danmark, spredtes historien om tegningerne verden rundt.

7. december 2005 blev tegningerne diskuteret på et møde i oIC - Organization of Islamic Conference - og 29. december udstedte Den Arabiske Ligas udenrigsministre en erklæring, hvori de udtrykte deres "overraskelse og harme over den danske regerings reaktion, der er skuffende, trods dens politiske, økonomiske og kulturelle bånd til den muslimske verden". Samtidig hermed havde imamer og andre ledende religiøse personer på initiativ fra det danske Islamisk Trossamfund rejst rundt i Mellemøsten for at få ministre, toppolitikere, og religiøse overhoveder i Mellemøsten til at protestere mod Danmark og offentliggørelsen af tegningerne.

Først i slutningen af januar - fire måneder efter at tegningerne første gang havde været bragt - begyndte boykotten mod danske varer og virksomheder. I Saudi Arabien blev borgerne indledningsvis via sms og e-mail opfordret til at boykotte 
danske varer og en række muslimske lærde truede med at opfordre muslimer over hele verden til boykot af danske og norske varer, efter at også den norske avis Magazinet havde valgt at bringe tegningerne af Profeten Muhammed.

Danske varer blev de følgende dage fjernet fra hylderne eller markeret med skilte der forklarede, at der var tale om danske produkter. Fra Saudi Arabien spredte boykotten sig til det meste af Mellemøsten, og ved fredagsbønnen den 27. januar opfordrede flere religiøse ledere til boykot. At boykotten startede i Saudi Arabien er ikke uden betydning. Saudi Arabien er som marked interessant; der er en årlig befolkningstilvækst på 4 procent og indkomsten er stigende, samtidig betegnes Saudi Arabien ofte som det land, hvis "accept" af et givet produkt eller produktkategori er en nøgle til Golfstaterne og i nogen grad det øvrige Mellemøsten.

27. januar krævede formanden for Dansk Industri, Hans Skov Christensen, i et åbent brev til Jyllands-Posten, at avisen forklarede sig og tog ansvar for de reaktioner, tegningerne havde vakt. Til avisen Politiken forklarede Hans Skov Christensen, at de danske virksomheder der var påvirkede af boykotten havde brug for en avisleder eller lignende for at mægle og forklare sig i den konflikt, som de uforvarende var havnet i. Få dage efter at boykotten var begyndt meddelte den dansksvenske mejerigigant Arla, at salget af virksomhedens produkter var stoppet helt i Saudi Arabien, og 3I. januar varslede virksomheden fyring af roo medarbejdere i både Danmark og Mellemøsten, som en direkte konsekvens af boykotten.

I begyndelsen af februar 2006 rasede krisen på sit højeste; danske og norske ambassadebygninger blev stormet og hærget i Damaskus, Jakarta og Beirut. I Teheran blev den danske ambassade 6 . februar forsøgt stormet og sat $\mathrm{i}$ brand, men det mislykkedes. Demonstrationerne og angrebene fortsatte i den følgende tid parallelt med boykotten - i Libyen blev bl.a. den italienske ambassade angrebet, i Pakistan blev også udenlandske restauranter og virksomheder som McDonald's angrebet og i bl.a. Indien, Indonesien, Afghanistan, Kenya og Fillipinerne var der uroligheder. Der blev ikke blot demonstreret mod Danmark, men også mod andre lande, hvor tegningerne var blevet trykt. Indtil dette tidspunkt var det især virksomheden Arla, der havde været genstand for såvel boykotten som for mediernes interesse, men I5. februar 2006 meddelte virksomheden Danisco, der producerer ingredienser som f.eks. sukker, at de havde fået annulleret flere ordrer som følge af "tegninge-sagen". I ugerne efter var Arla, Danisco og de øvrige danske virksomheder med interesser i Mellemøsten fortsat hårdt ramt af boykotten. Således anslog Arla i begyndelsen af marts-måned, at de økonomiske tab som følge af Profet-tegningerne og boykotten kunne opgøres til 400 mio. kr. Det estimerede tab var dog behæftet med stor usikkerhed, da det bl.a. forudsatte, at Arlas varer kort tid efter ville være tilbage på hylderne, ligesom omkostningerne ved den fremtidige tabte brandværdi heller ikke er medregnet.

I februar måned, da boykotten var mest udbredt, faldt den samlede månedlige eksport til Mellemøsten med I80 mio. kr. Hårdest ramt var mejerisektoren, der alene tegnede sig for et fald på II5 mio. kr. Erhvervsorganisationen HTSI gennemførte i samme måned en undersøgelse blandt 
sine medlemmer der viste, at 43 procent af de virksomheder, der handlede med lande der boykottede danske varer, var berørt af krisen, men at kun en tredjedel af virksomhederne havde oplevet deciderede tab som følge af krisen.

Sideløbende med boykotten, ambassadeafbrændingerne etc. har bl.a. Dansk Industri og HTSi, der er Danmarks erhvervsorganisation og arbejdsgiverforening, arbejdet hårdt for at begrænse skaderne for de danske virksomheder, der var ramt af boykotten. I form af rådgivning og kontakter til arabiske organisationer har Dansk Industri haft kontakt til de berørte virksomheder med interesser i regionen og samtidig søgt at formidle de danske virksomheders situation til de arabiske partnere.

Mejerigiganten Arla indrykkede med det formål at minimere boykotten annoncer $\mathrm{i}$ mere end 20 arabiske aviser, hvori virksomheden udtrykte sin forståelse for den reaktion, tegningerne havde vakt. I en af virksomhedens annoncer lød det bl.a.: “... vi forstår og respekterer jeres reaktion, der har ledt til boykot af vores produkter oven på denne uansvarlige og ulykkelige hændelse ...”. Annoncerne blev modtaget med blandede følelser på den politiske scene. Således udtalte regeringspartiet Venstres daværende politiske ordfører, Jens Rohde, om Arlas annocekampagne: "Arla er parat til at sælge sin bedstemor for at sælge sine varer i diktaturlande [...] Jeg kan slet, slet ikke forstå, at man kan tage så let på vores principper [...] Mine frihedsrettigheder er ikke til salg for to liter mælk." De modstridende interesser viste sig i de efterfølgende dage ganske tydeligt: Regeringen fastholdt den linje, at tegningerne var et udtryk for ytringsfrihed, og statsministeren under- stregede gentagne gange, at hverken han eller den øvrige regering havde mulighed for, som det blev krævet af muslimer verden over, at drage konsekvenser for den avis, der havde bragt tegningerne. Fronterne mellem dansk erhvervsliv og regeringen blev yderligere trukket op, da statsministeren $i$ et interview med Berlingske Tidende gav udtryk for, at det var hans opfattelse, at en del af dansk erhvervsliv havde udvist principløshed i sagen om tegningerne. Det fik koncernbestyrelsesformand i Grundfos, der på daværende tidspunkt havde mistet ordrer pga. krisen, Niels Due Jensen, til at give følgende svar: "Vi er ikke principløse, men vi har som ansvarlige ejere og ledere af danske erhvervsvirksomheder også en forretning at tage vare på. Vi skal sikre, at vores forretninger ikke lider unødige tab på grund af denne ulykkelige krise. Det er økonomisk omkostningsfrit for JyllandsPosten og åbenbart også for den danske regering at fastholde de tårnhøje principper i denne sag. Det har dansk erhvervsliv ganske enkelt ikke råd til efter min mening." Det traditionelle interessefællesskab mellem den liberale regering og erhvervslivet var under Muhammed-krisen således brudt, og fronterne trukket skarpt op, om end begge parter arbejdede for, at reaktionerne, herunder boykotten, skulle aftage og tilstanden normaliseres.

\section{Folkelig reaktion eller regimedikteret boykot?}

Boykotten har i Mellemøsten været betegnet som en "folkelig reaktion" og netop det at boykotten ikke skete på - direkte - opfordring fra de respektive landes regeringer betød, at det ikke var muligt for den danske regering via EU at rejse sagen $\mathrm{i}$ wTO, hvor Saudi Arabien fornylig var blevet medlem. 
En mulighed der blev bekræftet af Eus handelskommisær Peter Mandelson. Ikke desto mindre hjemkaldte Saudi Arabien 26. januar 2006 sin ambassadør fra Danmark, og tre dage senere gjorde Libyen det samme. Samtidig hermed havde Saudi Arabiens stormufti Sheikh Abdulaziz AlSheikh krævet, at Danmark straffede avisen Jyllands-Posten.

Der var dog undtagelser, hvor de mellemøstlige regeringer med al tydelighed viste, at de støttede boykotten: Den iranske handlesminister Massoud MirKazemi erklærede i februar 2006, at han, på baggrund af hvad han kaldte "den danske regerings ligegyldighed over for de blasfemiske tegninger af Profeten Muhammed", ikke tillod danske produkter eller mærker at passere tolden i Iran, at alle igangværende forretningsrelaterede forhandlinger var afbrudt og at eksisterende kontrakter mellem danske og iranske firmaer ville blive gennemgået. Ligeledes blev det forbudt for iranske delegationer og eksperter at besøge Danmark, og for danske delegationer og eksperter at besøge Iran. Beslutninger der havde ganske store konsekvenser for de danske virksomheder, der agerer i Iran.

\section{Eksporten på vej tilbage}

I midten af maj, dvs. mindre end et halvt år efter at boykotten begyndte, var der ændringer at spore, og eksporten var så småt på vej tilbage. Brancheorganisationen HTSI, vurderede i maj-måned 2006, at eksporten til Mellemøsten på dette tidspunkt var oppe på 75 procent af niveauet for samme periode året før. Vurderingen dækker dog over store variationer fra branche til branche: For medicinalindustrien var eksporten til Mellemøsten i første kvartal af 2006 på 200 mio. kr. sammenlignet med I43 mio. kr. i samme periode i 2005 - altså en stigning i netop den periode, hvor boykotten var aller hårdest. Boykotten var hvad angår medicinalvarer ganske markant i starten, men aftog hurtigt, hvorefter eksporten atter steg - endda til et niveau højere end før sagen om Profet-tegningerne.

Der er dog fortsat sektorer og virksomheder, der i modsætning til eksempelvis medicinalindustrien, fortsat er påvirket af boykotten. Som redegørelsen for den

\section{Den arabiske ligas udenrigsministre} udtrykte "overraskelse og harme over den danske regerings reaktion".

danske eksport til Mellemøsten viste, udgør fødevarer, særligt mejerivarer, en væsentlig del af den danske eksport til regionen. Det er samtidig en produktkategori, der for en stor del af varernes vedkommende, netop har været brand'et og markedsført ved at være danske produkter. Tillige gør det sig for denne type produkter gældende, at det er såkaldte Business-to-Consumer produkter, dvs. produkter der sælges til slutforbrugerne og ikke indgår i en videreproduktion eller bearbejdning. Denne type produkter er $i$ en situation som den mellemøstlige boykot af danske varer langt mere sårbar overfor "folkestemningen", da det er et produkt den enkelte forbruger vælger til og fra, og der tillige - for de fleste produkters vedkommende - må formodes at eksistere alternative valgmuligheder, således at alternativet til at fravælge produktet ikke er at måtte undvære. 
Arla Foods er den væsentligste danske aktør på det mellemøstlige mejerimarked, og har været repræsenteret på markedet siden I96o'erne ved smørmærket Lurpak og omsætter årligt for omtrent 2 mia. kroner i Mellemøsten. Alene i De Forenede Arabiske Emirater tegner Arla sig for op mod 70 procent af smørmarkedet, og netop denne store markedsandel medførte under boykotten, at flere butikker løb tør for smør, da konkurrenterne ikke i begyndelsen af boykotten havde mulighed for at levere i tilstrækkelige mængder til at erstatte Lurpak. Det ændrede sig imidlertid hurtigt, og siden starten af boykotten er den New Zealandske eksport af netop mejeriprodukter til Saudi Arabien, Indonesien og De Forenede Arabiske Emirater steget eksplosivt. Således er den New Zealandske eksport i første kvartal af 2006 steget med 22 procent, svarende til en stigning på 40 mio. kr. Samtidig er den Saudi Arabiske import af fødevarer faldet med 8 procent fra juli til december 2005, og den samlede nedgang i importen er på 6 procent - et fald der skyldes en svækket valuta, og dermed mindsket købekraft.

At New Zealandske mejerivareproducenter har formået at etablere sig på det saudiske dagligvaremarked vanskeliggør Arlas tilbagevenden til niveauet før Muhammed-krisen. Eksempelvis Lurpaksmør har været markedsført som et dansk produkt, hvor tilknytningen til Danmark og Skandinavien har været en del af markedsføringen. Det var en betegnelse, der indtil offentliggørelsen af de I2 satire-tegninger har været positiv i den saudiske forbrugerbevidsthed, men samtidig en markedsføring, der har vist sig yderst sårbar i en situation som den publiceringen af tegningerne forårsagede. Hvor danske og skandinaviske produkter før Muhammedtegningerne blev opfattet som lig kvalitet, var det i perioden umiddelbart efter tegningerne helt andre værdier sådanne produkter blev tillagt. I modsætning til Arla har det dansk-ejede rederi Mærsk markedsført sig som en international virksomhed og altså ikke en dansk. Det har muligvis haft en positiv effekt $\mathrm{i}$ en situation som Muhammed-krisen, hvor Mærsk i betydelig mindre grad end Arla har været ramt af boykotten. Hertil kommer, at Mærsk agerer i en fuldstændig anden sektor og med andre produkter end Arla. Ikke desto mindre viste Muhammed-krisen de danske virksomheder med interesser i Mellemøsten, at "Made in Denmark" ikke længere er garant for interesse og markedsandele.

I september 2006 - knap et år efter publiceringen af tegningerne - viser tal fra Danmarks Statistik, at sagen om de I2 tegninger har kostet Danmark en milliard kroner i tabt eksport, svarende til et fald i eksporten på I5,5 procent. Sideløbende med dette fald i eksporten til Mellemøsten er der dog samlet set sket en stigning i eksporten til udlandet, og i andet kvartal af 2006 steg den samlede eksport med 3,3 procent. En stigning der af økonomer betegnes som udtryk for tillid til dansk økonomi og et højt investeringsniveau, og ikke som et resultat af de "køb dansk kampagner”, der parallelt med Muhammedkrisen sendte efterspørgslen på danske varer i vejret andre steder i verden. Ifølge Danmarks Eksportråd er situationen for industrivarer atter normaliseret og danske virksomheder deltager som før i konkurrencen om de million og milliard kontrakter, der trods regionens rygte som politisk ustabilt og lovgivningsmæssigt uigennem- 
sigtigt er med til at gøre Mellemøsten til et særdeles attraktivt marked. For de danske eksportører af fødevarer er situationen en noget anden: Arla er igen at finde på hylderne i op imod halvdelen af de 50.000 forretninger, der før tegninge-sagen solgte deres varer, og virksomheden forventer at nå 50 procent af den normale målsætning i Mellemøsten inden næste år. Sagen om de I2 tegninger af Profeten Muhammed trækker måske nok ikke længere overskrifter verden over, men for de danske virksomheder i Mellemøsten, der afsætter fødevarer, og for den arabiske forbruger, er sagen ikke glemt.

\section{$\cdot f \cdot$}

I “Special Report Scandinavia: Trade”, meEd Weekly Special Report, 3I. august 200 I.

2 Med mindre andet er angivet er alle tal vedrørende eksport hentet fra Statistikbanken: http://www.statistik banken.dk/statbank5a/default.asp?w=IO24.

3 "Dansk Industri advarer om situationen i Iran", DR Nyheder/Penge, I3. januar 2006.

4 Befolkningstal baseret på Erslev Andersen, Lars, Søren Hove og Maj Vingum Jensen (red.): «Mellemøsthåndbogen - fakta om landene i Mellemøsten og Nordafrika». Syddansk Universitetsforlag, Danmark, 2005.

5 Danmarks Eksportråd i Dubai: http://www.dtcdubai. um.dk/da/menu/Markedsinformation/Markedsmulig heder/Sektoranalyser/SundhedMedicoBiotech/

6 Det Danske Udenrigsministerium: http://www.ambkairo. um.dk/da/menu/eksportraadgivning/markedsmulig heder/markedsoversigt/aktuellevaekstomr\%c3\%a5der /aktuellev\%c3\%a6kstomr\%c3\%a5der.htm.

7 Det Danske Udenrigsministerium: www.um.dk

8 "Muhammed-krisen dag for dag", DR: http://www.dr.dk /Nyheder/Temaer/Oevrige_temaer/2006/Tegninger/ Artikler/kronologir.htm.

9 "Muhammed-krisen dag for dag", DR: http://www.dr.dk /Nyheder/Temaer/Oevrige_temaer/2006/Tegninger/ Artikler/kronologiz.htm.

Io "Boykot mod Danmark: Muhammed-tegningerne", Politiken, I. sektion, S.I, 28. januar 2006

II Arla: http://www.arlafoods.dk/appl/HJ/HJ2OIAFD/ HJ20IDor.NSF/O/8689C4F6CE836CBECi257105004 $\mathrm{F}_{5} \mathrm{C} 67$.
I2 "Boykot mod Danmark: Ioo får fyreseddel i dag", Politiken, I. sektion, s. 7, 3I. januar 2006.

I3 Sullivan, Kevin: “Muslims' Fury rages Unababated over Cartoons; Demonstrators in I3 Countries Ignore Leaders' Appeals, Newspaper's Apology", The Washington Post, II. februar 2006 .

I4 "Boykot begynder at gøre ondt", Børsen, s.II, I6. februar 2006.

I5 Arla: http://www.arlafoods.dk/appl/HJ/HJ2OIAFD/ HJ20IDor.NSF/O/7B32666C7846ID54Ci257I25003 BA25I.

I6 HTSI: "Status på Muhammedkrisen", 3. august 2006, http://www.htsi.dk/4+Medlemskab/4.3+Nyhedsbreve/ 4.3.4+Oekonomiske+noegletal/4.3.4.I+2006/4.3.4.I.8+ August/4·3·4.8.4+Muhammed.htm.

I7 Henriksen, Morten (V): "Arlas knæfald for muslimer er ynkeligt”, Berlingske Tidende, I. sektion, S. I, 2I. marts 2006 .

I8 Grund, Jens og Svaneborg: “Muhammed-krisen: Erhvervslivet: Grundfos-formand: Vi har ikke råd til høje principper", Jyllands-Posten, I. sektion, s. 5, 27. februar 2006.

I9 “Arabia's Eu relations can weather the anger over Danish cartoons", Gulf States Newsletter, Issue 775, Io. februar 2006.

20 "Muhammed-krisen dag for dag", DR: http://www.dr.dk/ Nyheder/Temaer/Oevrige_temaer/2006/Tegninger/ Artikler/kronologi2.htm.

2I Beukel, Lone: "Sig Mecca til din cola - den religiøse forbruger?”, i Mellemøstinformation, 23. årgang, nr. 3, marts 2006.

22 Sobol, Thomas Aue og Attrup, Lars: "Comeback i Mellemøsten”, Jyllands-Posten, Erhverv og Økonomi, s. I, II. maj 2006.

23 HTSI: "Status på Muhammedkrisen", 3. august 2006: http://www.htsi.dk/4+Medlemskab/4.3+Nyhedsbreve/ 4.3.4+Oekonomiske+noegletal/4.3.4.I+2006/4.3.4.I.8+ August/4·3.4.8.4+Muhammed.htm.

24 Mixed reaction to Danish Firms in the region", Middle East Economic Digest (MEED), 2/10/2006, vol. 50, no. 6, S. 24 .

25 Muslimsk boykot har kostet én milliard i eksport", Internetavisen Jyllands-Posten, 8. september 2006: http://www.jp.dk/popup:print=3945578.

26 Horn, Ulrik: "Eksport nyder godt af europæisk opsving", Børsen, I. sektion, s. I5, IO. august 2006.

27 Iøcke, Lars Ole: “Økonomirapporten: Bud efter danske varer", Politiken, I. sektion, s. I3, 7. februar 2006.

28 Dyrskjøt, Mette: "Muhammed-krisen er afblæst for industrivarer”, Børsen, I. sektion, s. 9, 28. august 2006.

29 Carstensen, Niels H.: "Arla Foods er tilbage i Mellemøsten”, Børsen, I. sektion, s. 6, 5. september 2006. 